\title{
Aneta Dawidowicz, Sprawozdanie z ogólnopolskiej konferencji naukowej „Bezpieczeństwo Europy - Bezpieczeństwo Polski. Metamorfozy bezpieczeń- stwa i zagrożeń w XX i XXI wieku: nowa jakość polityczna, militarna, demo- graficzna, kulturowa", Lublin 24 listopada 2016 r.
}

Kwestie bezpieczeństwa należą do najważniejszych problemów współczesnego świata. Zagrożenia gospodarcze, klimatyczne, militarne, terrorystyczne to kluczowe sprawy, z którymi muszą się zmierzyć współczesne społeczeństwa. Podejmowane w tym zakresie badania naukowe stanowią odzwierciedlenie powyższych tendencji i zjawisk.

Pojęcie „bezpieczeństwo” można rozmaicie rozumieć. Kategoria „bezpieczeństwo społeczne" od niedawna stanowi przedmiot zainteresowania nauk zajmujących się problemami bezpieczeństwa państwa czy bezpieczeństwa narodowego. W przeszłości za podstawowy wyznacznik bezpieczeństwa narodowego uznawano gotowość do odparcia agresji zbrojnej. Przez stan zagrożenia bezpieczeństwa narodowego rozumiano sytuacje, w wyniku których zostają zagrożone podstawowe interesy narodu polskiego, zaś instytucje państwa w ich dotychczasowym kształcie nie są w stanie rozwiązać istniejących problemów społecznych. Współcześnie w dyskusjach o bezpieczeństwie państwa zaczęto utożsamiać tę problematykę zarówno z ochroną fizycznego trwania, integralności terytorialnej i trwałości instytucji państwa, jak i z rozwojem społecznym, gospodarczym, kulturalnym, poprawą jakości życia i wzrostem szeroko rozumianego dobrobytu. Nowe myślenie o bezpieczeństwie analizuje różne rodzaje zagrożeń bezpieczeństwa i opisuje jego kilka obszernych sektorów: wojskowy, polityczny, społeczny, ekonomiczny i ekologiczny.

24 listopada 2016 roku na Wydziale Politologii UMCS odbyła się ogólnopolska konferencja naukowa „Bezpieczeństwo Europy - Bezpieczeństwo Polski. Metamorfozy bezpieczeństwa i zagrożeń w XX i XXI wieku: nowa jakość polityczna, militarna, demograficzna, kulturowa”, którą zorganizowali: Zakład Myśli Politycznej, Zakład Systemów Politycznych, Ludowe Towarzystwo Naukowo-Kulturalne, Oddział w Lublinie.

Wydarzenie zostało objęte Patronatem Honorowym Jego Magnificencji Rektora Uniwersytetu Marii Curie-Skłodowskiej w Lublinie, Wojewody Lubelskiego, Prezydenta Miasta Lublin, Lubelskiego Komendanta Wojewódzkiego Policji, lubelskiego oddziału Polskiego Towarzystwa Nauk Politycznych. Patronat medialny objęły lokalne stacje radiowe i akademickie, m.in.: TVP3 Lublin, Polskie Radio Lublin, Radio „eR”, Telewizja Akademicka TV UMCS, Radio Centrum.

Konferencję zaszczyciło wiele znamienitych osób z kraju i zagranicy, związanych zarówno z nauką, jak i z wojskowością. W konferencji wzięło udział ponad 90 prelegentów, m.in. z: Akademii Sztuki Wojennej, Archiwum Państwowego w Zamościu, Katolickiego Uniwersytetu Lubelskiego Jana Pawła II, Instytutu Pamięci Narodowej, Krakowskiej Akademii im. Andrzeja Frycza Modrzewskiego, Państwowej Wyższej Szkoły Zawodowej w Płocku, Uniwersytetu w Białymstoku, Uniwersytetu Jagiellońskiego, Uniwersytetu Jana Kochanowskiego w Kielcach, Uniwersytetu Łódzkiego, Uniwersytetu Marii Curie-Skłodowskiej w Lublinie, Uniwersytetu Mikołaja Kopernika w Toruniu, Uniwersytetu Pedagogicznego im. Komisji Edukacji Narodowej w Krakowie, Uniwersytetu Przyrodniczo-Humanistycznego w Siedlcach, Uniwersytetu Rzeszowskiego, Uniwersytetu Wrocławskiego, Wyższej Szkoły Ekonomii i Innowacji w Lublinie, 
Wyższej Szkoły Przedsiębiorczości i Administracji w Lublinie, Wyższej Szkoły Stosunków Międzynarodowych i Komunikacji Społecznej w Chełmie.

Uroczystego otwarcia obrad dokonał Jego Magnificencja Rektor prof. dr. hab. Stanisław Michałowski oraz Prodziekan Wydziału Politologii prof. dr. hab. Marek Pietraś. Obradom plenarnym przewodniczyli: prof. dr hab. Ewa Maj, Kierownik Zakładu Myśli Politycznej Wydziału Politologii UMCS oraz prof. dr hab. Wojciech Sokół, Kierownik Zakładu Systemów Politycznych Wydziału Politologii UMCS.

Obrady podzielono na dwie zasadnicze części. W pierwszej części obrad plenarnych odbyły się dwa panele eksperckie. W pierwszym z nich głos zabrali: prof. dr hab. Marek Pietraś (Uniwersytet Marii Curie-Skłodowskiej w Lublinie), który zaprezentował problematykę dotyczącą „Dylematu paradygmatu bezpieczeństwa w XXI wieku”. Następnie głos zabrali płk Maciej Klisz (szef sztabu, Dowództwo Wojsk Obrony Terytorialnej) i płk Tadeusz Nastarowicz (dowódca 2. Lubelskiej Brygady Obrony Terytorialnej), którzy przedstawili kwestie dotyczące „Wojska Obrony Terytorialnej w systemie bezpieczeństwa państwa”. Następnie w imieniu komendanta Konrada Kańkowskiego zaprezentowano temat: „Cyberprzestępczość czyli cena rozwoju technologii”. Mgr Adam Kość (Miejskie Centrum Zarządzania Kryzysowego) zaprezentował temat: „Negocjacje kryzysowe w działaniach antykryzysowych”. Wystąpienie mgra Tadeusza Kabacińskiego zostało poświęcone sprawom „Agencji Bezpieczeństwa Wewnętrznego wobec problemu bezpieczeństwa w wymiarze lokalnym i krajowym”. Prof. dr hab. Robert Łoś (Uniwersytet Łódzki) omówił „Zagrożenia kulturowe Polski i Europy w XXI wieku”, natomiast prof. dr hab. Marcin Lasoń (Krakowska Akademia im. Andrzeja Frycza Modrzewskiego) podjął zagadnienie „Współpracy Policji i Sił Zbrojnych RP na rzecz bezpieczeństwa wewnętrznego państwa”. Mjr rez. dr Marek Gąska (Wyższa Szkoła Ekonomii i Innowacji w Lublinie) ukazał temat: „Umiędzynarodowiony wewnętrzny konflikt zbrojny - nowa generacja wojen czy kryzys tradycyjnej wojny?".

W drugim panelu ekspertów prof. dr hab. inż. Andrzej Żebrowski (Uniwersytet Pedagogiczny im. Komisji Edukacji Narodowej w Krakowie) omówił „Zagrożenie polityczne a walka informacyjna”. Prof. dr hab. Bolesław Sprengel (Uniwersytet Mikołaja Kopernika w Toruniu) zreferował „Polityczne przyzwolenie na inwigilację społeczeństwa czy ochrona bezpieczeństwa państwa”. Prof. dr hab. Mieczysław Ryba (Katolicki Uniwersytet Lubelski Jana Pawła II, Doradca Wojewody Lubelskiego) zaprezentował „Terror ukraiński na kresach wschodnich w okresie międzywojennym”. Dr Sławomir Franc przedstawił referat na temat: „Policja w systemie bezpieczeństwa województwa lubelskiego”. Prof. dr hab. Walenty Baluk (Uniwersytet Marii Curie-Skłodowskiej w Lublinie) omówił „Wojnę hybrydową Rosji na Ukrainie w latach 2014-2016”. Prof. dr hab. Jerzy Będźmirowski (Akademia Marynarki Wojennej im. Bohaterów Westerplatte) podjął „Bezpieczeństwo polskiej granicy morskiej w świetle nowego stanu politycznomilitarnego w basenie Morza Bałtyckiego w pierwszej dekadzie po zakończeniu II wojny światowej. Próba usystematyzowania”. Prof. dr hab. Patryk Pleskot (Instytut Pamięci Narodowej/Państwowa Wyższa Szkoła Zawodowa w Oświęcimiu) zreferował temat: „Bezpieczeństwo w czasach transformacji. Sprawozdania Nadwiślańskich Jednostek Wojskowych z lat 1989-1990". Ciekawym dopełnieniem omawianej problematyki stało się wystąpienie Pana Ja- 
rosława Bucia (Główny Instruktor Węgiersko-Polskiej Szkoły Szermierki Szablą) zatytułowane „Wartość bojowa i narodowa szabli”.

Następnie uczestnicy konferencji udali się na dalsze obrady, które odbyły się w siedmiu panelach tematycznych. Sekcje tematyczne prowadzili: prof. dr hab. Alicja Wójcik, prof. dr hab. Czesław Maj, dr Eleonora Kirwiel, dr Łukasz Lewkowicz, dr Kamil Mazurek, dr Marcin Wichmanowski. Panel pierwszy poświęcono militarnym wymiarom bezpieczeństwa. W panelu drugim omówiono niemilitarne wymiary bezpieczeństwa. W panelu trzecim dyskusje i referaty koncentrowały się wokół bezpieczeństwa Polski: w dwóch wymiarach - historycznym i współczesnym. Panel czwarty poświęcono regionalnym wymiarom bezpieczeństwa. Kolejny panel piąty dotykał „Kwestii zagrożenia i reasekuracji bezpieczeństwa”. Polityczne i kulturowe aspekty bezpieczeństwa stały się tematem przewodnim podjętym w panelu szóstym. Ostatni siódmy panel ukazał geopolityczny wymiar bezpieczeństwa. Różnorodność i bogactwo problematyki poruszanej przez kilkudziesięciu autorów podczas konferencji odzwierciedla trudny i skomplikowany charakter pojęcia „bezpieczeństwo”.

Konferencja „Bezpieczeństwo Europy - Bezpieczeństwo Polski. Metamorfozy bezpieczeństwa i zagrożeń w XX i XXI wieku: nowa jakość polityczna, militarna, demograficzna, kulturowa" stanowiła niezwykle udane przedsięwzięcie zarówno pod względem naukowym, jak i organizacyjnym. Można konkludować, że organizatorom udało się zaprosić do wspólnej debaty bardzo liczne, interdyscyplinarne grono badaczy, ekspertów i praktyków. Uczestnicy konferencji zgodnie podkreślali wysoki poziom merytoryczny prezentowanych referatów i dyskusji. Przebieg i znaczne zainteresowanie tematyką konferencji potwierdzają potrzebę organizowania podobnych przedsięwzięć w przyszłości. Nadmienić wypada, że organizatorzy zapowiedzieli wydanie materiałów pokonferencyjnych w formie monografii naukowej. 